\title{
Effects of processing conditions on structural and functional parameters of whipped dairy emulsions containing various fatty acid compositions
}

\author{
A. Bazmi ${ }^{*}{ }^{1}$ and P. Relkin $\dagger$ \\ ${ }^{*}$ Food Science and Technology Group, Faculty of Agriculture, University of Tabriz, 51666 Tabriz, Iran \\ †AgroParisTech, Department of Science and Engineering for Food and Bioproducts 1, Avenue des Olympiades, F-91744 Massy, France
}

\begin{abstract}
An understanding of the effects of processing parameters can be applied to formulate emulsions with higher unsaturated fatty acid content. Emulsions using the typical ice cream formulation were produced by anhydrous milk fat alone or in a mixture with either olein or stearin at a 2:1 weight ratio. Effects of both pasteurization holding time $\left(40\right.$ or $120 \mathrm{~s}$ at $80^{\circ} \mathrm{C}$ ) and aging time (ranging from 2 to $24 \mathrm{~h}$ ) on the structural and whipping properties of the emulsions were studied. Effects of these processing conditions on emulsion structural characteristics were determined using laser light-scattering measurements, rheological properties, microscopic observations, and image analyses of the whipped emulsions. Furthermore, foaming properties of these emulsions were compared and discussed with regard to effects of both processing and composition on properties of the emulsions, such as thixotropy and sensitivity to shearing. We observed changes in fat globules when different pasteurization holding times were applied, but no changes in either apparent viscosity values or sensitivity to shearing were traceable. However, enrichment of milk fat with the olein fraction increased the whipping ability of the emulsions, as evaluated in terms of overrun and the homogeneity of air bubbles, whatever the aging time. The lowest monodispersity of air bubbles was observed in the formulation rich in stearin. After $24 \mathrm{~h}$ of aging, this formulation showed the same overrun as the emulsion made with anhydrous milk fat. Increasing the aging time decreased the overrun by approximately $30 \%$, and increasing the pasteurization holding times decreased it by approximately $20 \%$. In general, in our conditions, increasing the aging time and unsaturated fatty acid content reduced changes in the dynamic rheological and structural properties observed just after production of the emulsions, whatever the pasteurization holding time or fat composition applied.
\end{abstract}

Received August 25, 2008.

Accepted March 5, 2009.

${ }^{1}$ Corresponding author: bazmi@tabrizu.ac.ir
Key words: dairy emulsion, whipping, triglyceride, ice cream pasteurization

\section{INTRODUCTION}

Whipped dairy emulsions are made by introducing air into oil-in-water emulsions. In whipped emulsions, gas bubbles are dispersed in a matrix of a high-viscosity serum phase and are surrounded by partially coalesced fat at the air-serum interface. Several factors affect the structural properties of whipped dairy cream, including fat content and its thermal properties, processing parameters (particularly, the pasteurization, homogenization, aging, and foam-formation conditions), the addition of stabilizers, the addition of emulsifiers, and the composition of milk proteins (Bruhn and Bruhn, 1988; Berger, 1990; Marshall and Arbuckle, 1996; Smith et al., 2000a; Bazmi et al., 2006, 2007; Indrawati et al., 2008). A higher whipping speed enhances foam formation and stability. Globular milk proteins produce larger air bubbles with a higher stability compared with nonglobular milk proteins (Indrawati et al., 2008). The ease and extent of partial coalescence are affected by the composition of milk fat and by its crystalline state (Goff, 1997b; Bazmi et al., 2007).

Ice cream emulsions are cooled to approximately $4^{\circ} \mathrm{C}$ after the pasteurization and homogenization steps. Thereafter, the cooled emulsions are left to age and are then whipped while they are freezing. Storage lasts up to $24 \mathrm{~h}$ for aging. During this aging period, milk fat crystallization, reorganization of milk fat globule surfaces, and hydration of proteins and hydrocolloids take place (Berger, 1990; Olsen, 1992; Goff, 1997a). It has been shown that fat crystals in the oil droplets and at the interface have effects on emulsion stability (Rousseau, 2000). During aging at $4^{\circ} \mathrm{C}$, an increase in mix viscosity can be observed (Goff, 1997a) because of the hydration of milk proteins and stabilizers, liquid fat crystallization, and displacement of proteins from the fat globule interfaces (Berger, 1990). Other studies have shown that the aging period should allow the formation of a high percentage of crystallized fat for optimization of the overrun and freezing steps applied in ice cream 
manufacture (Boode and Walstra, 1993; Herrera et al., 1999), with consequences for the partial coalescence of fat droplets (Berger, 1990; Rahalkar, 1992; Goff, 1997b; Herrera et al., 1999; Davies et al., 2000).

Milk fat, which is often used in foamed dairy foods, consists of a wide diversity of saturated and unsaturated fatty acids and several hundred of different triacylglycerols (TAG) (Gresti et al., 1993). In the milk fat industry, anhydrous milk fat (AMF) is commonly fractionated, and the resulting fractions contain a large proportion of either saturated (high melting temperature) or unsaturated (low melting temperature) TAG. Such milk fat fractions can be used as ingredients in various formulations. The high-melting fraction would be suitable for baking purposes. Other examples are in the chocolate and ice cream industries, which demand a high-melting fat content for coatings. The low-melting fraction would be of interest in the production of butter with easier spreading characteristics. These fractions, when used in ice cream formulations, have effects on their physical and sensory characteristics (Abd ElRahman et al., 1997).

Heat treatment of dairy whipping emulsions, which is desirable to increase shelf life, results in some changes in their rheological, structural, and whipping properties, such as whipping time, overrun, and stability against drainage (Graf and Muller, 1965; Smith et al., 2000a; Bazmi et al., 2007). From the extensive literature of the last 20 years, we know that the heat-sensitive whey proteins in milk, particularly $\beta$-LG, denature at the pasteurization temperature (Relkin, 1996; Kulozik et al., 2003; Livney et al., 2003), and that by physicochemical interactions, protein denaturation subsequently affects the structural characteristics and processing capacity (e.g., whipping properties) of dairy emulsions (Sourdet et al., 2003). Caseins are more stable against the pasteurization temperature, and they interact only with the whey proteins (Livney et al., 2003; Sourdet et al., 2003). As a consequence of protein denaturation caused by the pasteurization treatment, the whey proteins become more surface active and act as emulsifiers (Marshall and Arbuckle, 1996; Sourdet et al., 2003). At this temperature, milk fat melts and the emulsifiers in the formulation are promoted to develop the emulsion structure. The functional properties of milk proteins are particularly affected by 2 major pasteurization parameters included, the temperature and the holding time of pasteurization. Denaturation of $\beta-\mathrm{LG}$ at temperatures higher than $68^{\circ} \mathrm{C}$ is the immediate consequence of heating of milk proteins, which is followed by their aggregation and reaction with $\kappa$-CN (Baer et al., 1976; Dannenberg and Kessler, 1988; Kulozik et al., 2003; Livney et al., 2003).
Although several studies have been conducted on the role of functional ingredients, such as milk proteins, emulsifiers, and fat, on ice cream emulsions (Adapa et al., 2000; Bolliger et al., 2000; Sourdet et al., 2002; Granger et al., 2003; Palanuwech and Coupland, 2003; Peamprasart and Chiewchan, 2006), only a few concern the effect of processing parameters on the physical and whipping properties of ice cream mix emulsions during aging. In recent studies, we have investigated the effects of milk fat composition on the crystallization behavior of fat globules and their resistance to aggregation or coalescence in ice cream mix emulsions (Bazmi and Relkin, 2006), their effects on the rheological properties of ice cream mixes during aging (Bazmi et al., 2008), and their effects on aeration properties (Bazmi et al., 2007). In the first paper, we reported the effects of various levels of high- or low-melting fractions of AMF on its thermal transition and stability in bulk and in an emulsified state. Our studies showed that when part of the AMF content of the formulations was replaced by its fractions, it had a considerable effect on the thermal transition behavior of the bulk and emulsified milk fat composition and on the physical stability of the emulsions. In another work (Bazmi et al., 2008), we investigated the effects of milk fat composition of aged emulsions having different rheological properties on the aeration characteristics of the emulsions. There, we showed differences in shear stability in the emulsions, which were related to the rate of fat crystal development in the dispersed phase droplets and their interaction with a weak network of biopolymers. In the third paper, we discussed the effects of the aforementioned parameters on the functional properties of various TAG compositions, which influenced the aeration and stability of the foamed emulsions. In the present study, we investigated the effects of heat treatment and quiescent aging for 2 - and 24 -h periods at $4^{\circ} \mathrm{C}$ on the physical and whipping behavior of ice cream mix emulsions in which AMF was partially replaced by a milk stearin- or olein-enriched fraction.

\section{MATERIALS AND METHODS}

\section{Emulsion Preparation}

Ice cream mix emulsions were prepared using milk fat samples provided by Lactalis (Laval, France). They contained milk fat (10 wt\%), nonfat milk solids (10 wt\%), sucrose (15 wt\%), and Cremodan SE30 (0.5 wt\%; Danisco, Copenhagen, Denmark). Cremodan SE30 is a commercial blend of stabilizers (locust bean gum, sodium alginate, guar gum, and carrageenan) and mono- and diglyceride emulsifiers. For preparation of 
the mixes, either AMF alone was used, or a mixture of $\mathrm{AMF}$ and stearin (AMF/S) or $\mathrm{AMF}$ and olein $(\mathbf{A M F} / \mathbf{O})$ was used at a 2:1 weight proportion. The premix systems were pasteurized in a tubular heat exchanger at $80^{\circ} \mathrm{C}$ with different holding times (40 or 120 s), homogenized in 2 stages at 110/40 bar total pressure using a Niro homogenizer (Niro Soavi S.P.A., Gea, Italy), and immediately cooled to $4^{\circ} \mathrm{C}$ with a tubular heat exchanger. The emulsions were then aged at this temperature for 2 or $24 \mathrm{~h}$ before characterization.

\section{Particle Size Distribution}

The emulsions, which were stored at $4^{\circ} \mathrm{C}$, were analyzed for their fat droplet-size distributions (Malvern Mastersizer-MS 1000, Malvern Instruments, Orsay, France) based on an independent mathematical model. This model was based on the Mie and Fraunhofer optical diffraction theories. According to these theories, particle sizing is done by assigning the size of equivalent spheres. Samples of the emulsions were taken from the middle part of $40-\mathrm{mL}$ bottles, dispersed in distilled water or in a solution of $1 \%$ SDS for dissociation of flocculated fat globules, and then diluted (approximately 1:1000) with distilled water in the sample chamber. Measurements were done at room temperature. The code of the presentation factor, which was used by the machine to calculate the fat droplet-size distributions, was based on the optical parameters of the emulsion (Sourdet et al., 2002). It was chosen after measuring the refractive index (Abbe Atago 3T refractometer, Atago, Tokyo, Japan) of dispersed fat relative to water (1.10) and the absorbance (0.1) at $633 \mathrm{~nm}$ (Cary 100 spectrophotometer, Varian, Les Ulis, France). Changes in structural stability against flocculation or coalescence as functions of milk fat composition and aging time were evaluated by using the mean volumetric diameter [Mie mean diameter, $\mathbf{d}_{(4.3)}$ ]. The $\mathrm{d}_{(4.3)}$ is the average diameter of the particles based on the unit volume (mass) of a particle: $\mathrm{d}_{(4.3)}=\Sigma \mathrm{n}_{\mathrm{i}} \mathrm{d}_{\mathrm{i}}^{4} / \Sigma \mathrm{n}_{\mathrm{i}} \mathrm{d}_{\mathrm{i}}^{3}$, where $\mathrm{n}$ is the number of particles having a diameter of $\mathrm{d}$.

\section{Rheological Properties}

The rheological properties were studied at $4^{\circ} \mathrm{C}$ using a Carri-Med CSL-100 rheometer (TA Instruments, Surrey, UK) with a cone (60 $\mathrm{mm}$ diameter, $4^{\circ}$ ) and plate geometry. Ice cream mix emulsions were gently sampled from the middle part of the $40-\mathrm{mL}$ bottles with a spoon, and samples were deposited on a precooled $\left(4^{\circ} \mathrm{C}\right)$ plate 10 min before beginning the experiment.

Viscosity. For apparent viscosity measurements, the emulsions were submitted to a 10-min shearing cycle from 3 to $300 \mathrm{~s}^{-1}$, and back. Up and down viscosity val- ues were determined at $5 \mathrm{~s}^{-1}$ and were used to evaluate changes in the apparent thixotropy of emulsions after different storage times at $4^{\circ} \mathrm{C}$. All the measurements were done in triplicate.

Oscillatory Rheometry. Mechanical spectra were determined by oscillatory measurements by applying a logarithmic frequency sweep (10 points) from 5 to 0.01 $\mathrm{Hz}$ at $4^{\circ} \mathrm{C}$ (Vega and Goff, 2005). The first frequency sweep was followed by a shearing step at $100 \mathrm{~s}^{-1}$ for 1 min, and by a time sweep $\left[\mathrm{G}^{\prime}(t)\right.$, where $\mathrm{G}^{\prime}$ is the storage modulus and $t$ is time] at $0.05 \mathrm{~Hz}$ for $10 \mathrm{~min}$. This procedure was applied to monitor the structural recovery after shearing. The $\mathrm{G}^{\prime}$ values at $0.05 \mathrm{~Hz}$ during the frequency sweep, and at $t=10 \mathrm{~min}$ of the time sweep $\left[\mathrm{G}^{\prime}(t=10)\right]$ were applied to the characterizations of mix structural recovery. This was described by a recovery parameter, shear sensitivity $\left(\boldsymbol{R}_{\mathbf{r}}\right)$, defined by the ratio of $\mathrm{G}^{\prime}(t=10)$ after shearing (at $100 \mathrm{~s}^{-1}$ for $1 \mathrm{~min}$ ) and $\mathrm{G}^{\prime}$ values at $0.05 \mathrm{~Hz}$, before shearing:

$$
R_{\mathrm{r}}(t)=\frac{\mathrm{G}^{\prime}(t=10)}{\mathrm{G}^{\prime} \text { (before shearing) }} .
$$

Before the frequency test, a shear amplitude sweep test at a constant frequency $(0.05 \mathrm{~Hz})$ was carried out to determine the linear viscoelastic domain of the samples. In practice, a constant stress amplitude of $0.1 \mathrm{~Pa}$ was shown to correspond to the linear viscoelastic domain for all the oscillatory measurements. The measurements were carried out for each of the 3 emulsion types after various aging times at $4^{\circ} \mathrm{C}$ after their preparation.

\section{Whipping Procedure}

The aged emulsions were whipped for $10 \mathrm{~min}$ at $4^{\circ} \mathrm{C}$ by using a domestic mixer (Kenwood, Kenwood Electronics, Tokyo, Japan) at the maximum speed. To maintain similar temperature conditions throughout the whipping tests, all the emulsions were whipped inside a walk-in refrigerator at $4^{\circ} \mathrm{C}$, using the same emulsion volume $(1 \mathrm{~L})$ and with the temperature controlled to within $1^{\circ} \mathrm{C}$ during whipping. Under the above-mentioned conditions, whipping the emulsions for $10 \mathrm{~min}$ led to the aeration of the entire mix volume, without any liquid drainage for at least $30 \mathrm{~min}$. The volume fraction of air incorporated into the emulsions (overrun) was evaluated immediately after whipping by sampling from the middle of the beaker. This was defined as the weight ratio of air incorporated to the initial weight of the emulsion. The overrun value was determined in triplicate independently for each of the 3 ice cream mix preparations. 
Table 1. Effects of pasteurization holding time (40 or $120 \mathrm{~s}$ ) at $80^{\circ} \mathrm{C}$ on whipping and on some physical properties of ice cream mix made from anhydrous milk fat, and on aging time at $4^{\circ} \mathrm{C}(2$ or $24 \mathrm{~h})$

\begin{tabular}{|c|c|c|c|c|}
\hline \multirow[b]{2}{*}{ Item } & \multicolumn{2}{|c|}{$2 \mathrm{~h}$} & \multicolumn{2}{|c|}{$24 \mathrm{~h}$} \\
\hline & $40 \mathrm{~s}$ & $120 \mathrm{~s}$ & $40 \mathrm{~s}$ & $120 \mathrm{~s}$ \\
\hline Shear sensitivity $\left(R_{\mathrm{r}}\right)$ & $1.6 \pm 0.13$ & $2.28 \pm 0.52$ & $1.21 \pm 0.08$ & $1.18 \pm 0.23$ \\
\hline $\mathrm{d}_{(4.3)}{ }^{1}(\mu \mathrm{m})$ & $1.8 \pm 0.1$ & $2.0 \pm 0.2$ & $2.0 \pm 0.1$ & $2.5 \pm 0.1$ \\
\hline Viscosity, $\mathrm{Pa} \cdot \mathrm{s}$ at $5 \mathrm{~s}^{-1}$ & $0.46 \pm 0.04$ & $0.45 \pm 0.04$ & $0.48 \pm 0.02$ & $0.43 \pm 0.01$ \\
\hline Overrun (\%) & $116 \pm 4$ & $98 \pm 2$ & $85 \pm 2$ & $72 \pm 3$ \\
\hline
\end{tabular}

${ }^{1} \mathrm{~d}_{(4.3)}=$ Mie mean diameter.

\section{Air Bubble Size Distribution in the Whipped Emulsions}

Immediately after application of the whipping test, small amounts of foamed emulsion samples were taken from the middle of the beaker, placed on glass slides, and then carefully distributed to provide a flat plane for light microscopy observations. The light microscope (Carl Zeiss, Göttingen, Germany) was equipped with a color video camera (Spot insight color, Diagnostic Instruments Inc., Sterling Heights, MI). At least 2 slides of each foam sample were prepared, and approximately 8 different images were taken, for a total of 1,400 to 1,700 air cells. The images were provided only from areas that were visually identified to be a good representation of the air bubbles in the sample. Image analysis of air cells was then performed using Image-Pro Plus software (The Proven Solution, Media Cybernetics, Bethesda, MD). We counted and analyzed only air bubbles inside the micrographs. Moreover, the bubbles located at the perimeter of micrographs were not counted. A program was written using Matlab programming software (The MathWorks Inc., Natick, MA) to analyze air bubble size distribution information in the whipped emulsions.

\section{RESULTS AND DISCUSSION}

\section{Effect of Heat Treatment Using AMF}

The effects of pasteurization holding times on the physical properties of the emulsions made from AMF are presented in Table 1. The size distribution of the fat droplets in the dispersed phase of the samples, as measured by a laser light particle size analyzer, was investigated to study their stability against fat droplet aggregation or coalescence, depending on the pasteurization holding time and the aging time at $4^{\circ} \mathrm{C}$. These measurements exhibited an increase in the $\mathrm{d}_{(4.3)}$ of fat droplets during aging at $4^{\circ} \mathrm{C}$. The $\mathrm{d}_{(4.3)}$ of the emulsion droplets increased during aging time by a significant amount $(P<0.05)$ for the emulsions held for $120 \mathrm{~s}$ at pasteurization, being augmented from 2 to $2.5 \mu \mathrm{m}$.
These results could suggest that there was increased partial coalescence in severely heated emulsions. This was due to the agglomeration or clustering of partially crystallized fat droplets, which were held together by fat crystals and liquid fat as long as the crystalline fat was not melted. This showed the effect of heat treatment on the dispersed phase of the emulsion. Smith et al. (2000a,b) showed previously that higher heat treatments of dairy emulsions cause the rupture of the fat globule protective membrane and make them sensitive to partial coalescence and to consequent agglomeration or clustering. They also showed that higher heat treatments of emulsions cause larger droplet sizes with less homogeneity.

Viscosity of the emulsions was evaluated at $4^{\circ} \mathrm{C}$ by applying 10-min shear cycles from 3 to $300 \mathrm{~s}^{-1}$, and back. These measurements indicated pseudoplastic and thixotropic rheological behavior in the emulsions (Figure 1). The presence of hydrocolloid stabilizers in the 3 formulations, which are known to be good water-binding agents (e.g., guar gum) and to create a gel-like structure (e.g., carrageenan), are responsible for the thixotropic rheological behavior of the emulsions. Moreover, the thixotropic behavior of the emulsions caused by the gellike structure created by the stabilizers, such as locust bean gum and carrageenan, was further enhanced by the presence of milk proteins in our systems (Sherman, 1968; Goff et al., 1999; Michon et al., 2005). The up and down apparent viscosity values $\left(5 \mathrm{~s}^{-1}\right)$ determined for fresh preparations and preparations stored at $4^{\circ} \mathrm{C}$ for $24 \mathrm{~h}$ are shown in Table 1. This rheological parameter did not show any significant variation caused by the pasteurization holding time or aging period.

Rheological measurements in dynamic mode may be related to the relaxation behavior of the network formed by particle interactions. Changes in viscoelastic properties, caused by heat treatment of the premix and aging time at $4^{\circ} \mathrm{C}$, were examined by oscillatory rheometry for the ice cream mix emulsions. A rheogram frequency sweep from 5 to $0.01 \mathrm{~Hz}$ is shown in Figure 2 for the AMF emulsion $1 \mathrm{~h}$ after its preparation. The rheological spectra obtained showed slightly higher values for 


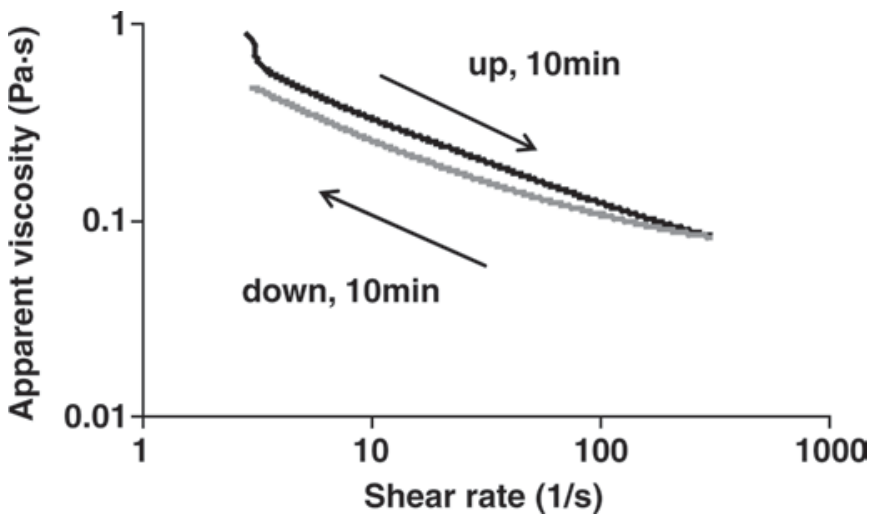

Figure 1. Apparent viscosity evolution of the emulsion made with AMF (emulsion containing anhydrous milk fat alone as the source of milk fat in the formulation) and pasteurized at $80^{\circ} \mathrm{C}$ for $40 \mathrm{~s}$. Measurement made after $24 \mathrm{~h}$ of aging of the emulsion at $4^{\circ} \mathrm{C}$.

$\mathrm{G}^{\prime}$ than $\mathrm{G}^{\prime \prime}$ (loss modulus), indicating that emulsions behaved like weak physical gel networks. The same spectra in the rheological behavior were obtained in the other studies on ice cream mix emulsions (Sherman, 1966; Adapa et al., 2000; Eisner et al., 2005; Granger et al., 2005).

The elastic modulus of the emulsions was reduced by increasing the aging time from 2 to $24 \mathrm{~h}$ at frequency sweeps from 5 to $0.01 \mathrm{~Hz}$ (Figure 3). Likewise, as shown in Figure 3, the emulsions submitted to a higher pasteurization holding time showed a decrease in the $\mathrm{G}^{\prime}$.

The structural recovery of emulsions after applying a shearing step at $100 \mathrm{~s}^{-1}$ for $1 \mathrm{~min}$ was based on the measurements of $\mathrm{G}^{\prime}$ and $\mathrm{G}^{\prime \prime}$ at $0.05 \mathrm{~Hz}$ for 10 min. After the shearing step, $G^{\prime}$ and $G^{\prime \prime}$ decreased, and then progressively increased during the remaining

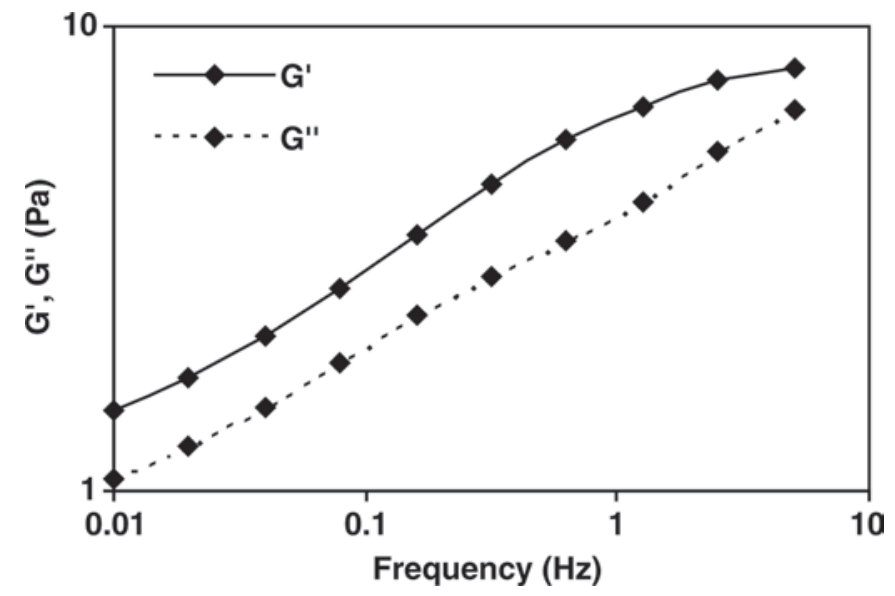

Figure 2. Dynamic storage $\left(\mathrm{G}^{\prime}\right)$ and loss $\left(\mathrm{G}^{\prime \prime}\right)$ moduli of anhydrous milk fat emulsions at $4^{\circ} \mathrm{C}$ after $2 \mathrm{~h}$ of aging, at a frequency sweep. The emulsion was pasteurized at $80^{\circ} \mathrm{C}$ for $120 \mathrm{~s}$, and the stress amplitude of the measurement was $0.1 \mathrm{~Pa}$. time. Lower shear rates can break only weak interaggregate bonds, whereas higher shear rates result in the rupture of stronger intraaggregate bonds (Sherman, 1966), with a consequent reduction of the $\mathrm{G}^{\prime}$ and $\mathrm{G}^{\prime \prime}$ modulus. After reforming, the inter- and intraaggregate bonds in the emulsion help it to regain its viscoelastic properties with various shear rates and up to a new state. It was observed that during the first minutes after shearing, $G^{\prime}$ and $G^{\prime \prime}$ increased $\left(G^{\prime}\right.$ more rapidly than $\left.G^{\prime \prime}\right)$ toward plateau values, which were higher than before shearing (Bazmi et al., 2008). Structural recovery differed, depending on the milk fat composition and the storage time at $4^{\circ} \mathrm{C}$, and was evaluated through $R_{\mathrm{r}}$ values (equation [1]). Results reported in Table 1 show that structural recovery decreased with pasteurization holding time, from 1.60 to 1.21 for the AMF emulsion after $2 \mathrm{~h}$ of aging and from 2.28 to 1.18 after $24 \mathrm{~h}$ of aging. These results show that increasing the aging time reduced the effects of heat treatment on the $R_{\mathrm{r}}$ of the emulsions. This could have been due to structural organization parameters of the fat droplets (fat crystallization and interfacial adsorption properties of proteins) and to continuous-phase structural properties (stabilizers or protein hydration and their interactions) in multiphasic dispersed systems. Denaturation of whey protein is the immediate effect of heating on dairy products. It is then followed by aggregation and finally by reaction with the globular proteins of milk, particularly к-CN (Baer et al., 1976; Dannenberg and

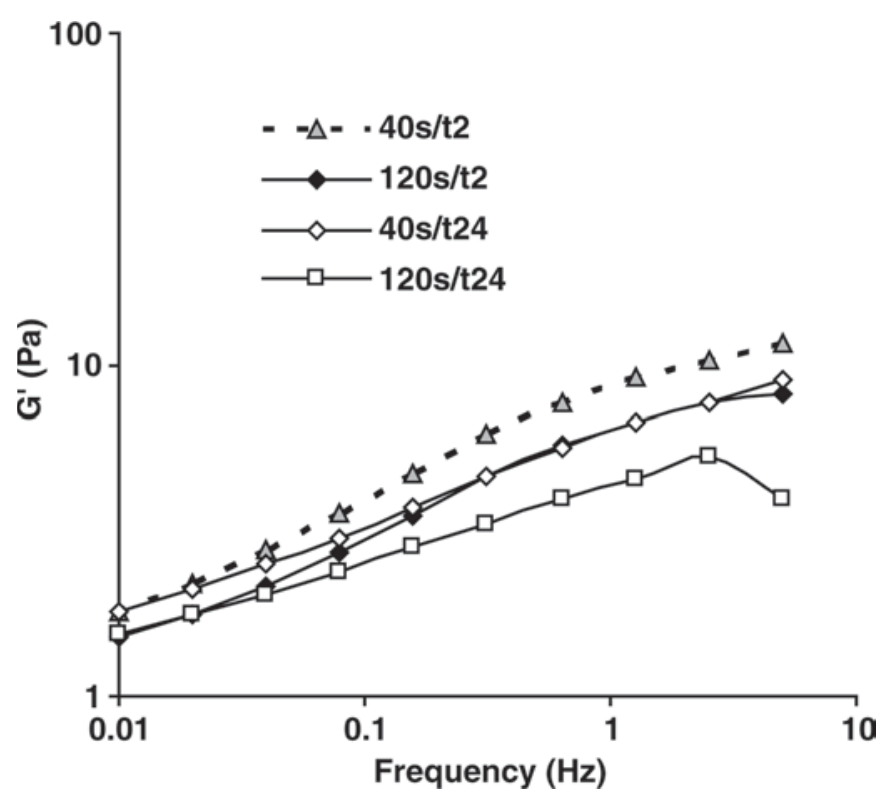

Figure 3. Dynamic storage modulus $\left(\mathrm{G}^{\prime}\right)$ of anhydrous milk fat emulsions submitted to a 40 - or 120 -s pasteurization holding time at $4^{\circ} \mathrm{C}$ after $2 \mathrm{~h}(\mathrm{t} 2)$ or $24 \mathrm{~h}$ ( $\left.\mathrm{t} 24\right)$ of aging, at a frequency sweep (stress amplitude of $0.1 \mathrm{~Pa})$. 
Kessler, 1988; Kulozik et al., 2003; Livney et al., 2003). In addition, denaturation of the whey proteins has an effect on their capacity to interact with $\mathrm{CN}$ to create a stabilizing network in the fat and serum and then, while foaming, between air and fat (Sourdet et al., 2002, 2003; Relkin and Sourdet, 2005). These effects explain how heat treatment can be involved in higher $R_{\mathrm{r}}$ of the emulsions submitted to a higher pasteurization holding time at early aging times $(2 \mathrm{~h})$. During the aging time, rearrangement of the fat globule membranes and substitution of fat globule membrane proteins with emulsifiers, creating a new structure in the aqueous phase with swelled hydrocolloids, reduces the sensitivity of the structure to shearing.

The foaming ability of ice cream mixes made with AMF was measured after 10 min of whipping at $4^{\circ} \mathrm{C}$. As shown in Table 1, by increasing the aging time from 2 to $24 \mathrm{~h}$, the whipping ability (overrun) of the mixes decreased. These results present a reduction of approximately $30 \%$ in overrun, whatever the pasteurization holding time. It was also shown that overrun was inhibited by increasing the pasteurization holding time by approximately $20 \%$ after $2 \mathrm{~h}$ of aging. This reduction decreased by $10 \%$ after $24 \mathrm{~h}$ of storage at $4^{\circ} \mathrm{C}$. Accordingly, further heat treatment and aging time seemed to have a negative effect on whipping ability, probably because of the increase in fat globule size. The $d_{(4.3)}$ of fat globules increased by raising the aging time as well as the pasteurization holding time (Table 1). Previous studies on the effect of heat treatment on the foaming ability of dairy emulsions showed that increasing the heat treatment resulted in a lower overrun and higher whipping time (Graf and Muller, 1965; Bruhn and Bruhn, 1988). Thermal analyses of $\beta$-LG have shown 2 denaturation temperatures, one near $80^{\circ} \mathrm{C}$ and another near $140^{\circ} \mathrm{C}$ (De Wit and Klarenbeek, 1981). Denatured $\beta$-LG may form complexes with $\kappa$-CN and $\alpha$-LA (Baer et al., 1976; Dannenberg and Kessler, 1988; Kulozik et al., 2003; Livney et al., 2003), resulting in changes in the membrane structure at the milk fat droplets and the air-fat interfaces, which may explain the changes in viscoelastic properties (shown above) associated with destabilization of the whipped emulsion.

\section{Effect of Aging Time and Milk Fat Composition}

Whipping properties of the ice cream mix emulsions made with various compositions of milk fat were studied as a function of their aging time (2 and $24 \mathrm{~h})$ and these results are presented in Table 2. It was shown that, like the AMF emulsion, increasing the aging time reduced the overrun of the $\mathrm{AMF} / \mathrm{O}$ and $\mathrm{AMF} / \mathrm{S}$ emulsions, with a higher overrun for the emulsion enriched with the olein fraction (AMF/O emulsion). In the $\mathrm{AMF} / \mathrm{S}$ emulsion, which contained AMF rich in stearin, the overrun was reduced from $127 \%$ after $2 \mathrm{~h}$ of aging, to $87 \%$ after $24 \mathrm{~h}$ of aging. The same tendency was observed for the AMF and AMF/O emulsions, indicating the evolution of the whipping properties of the emulsions during aging. After $24 \mathrm{~h}$ of aging of the emulsions, a 10-min whipping resulted in overrun values close to $85 \%$ for the AMF and AMF/S emulsions, and close to $105 \%$ for the AMF/O emulsion (Table 2 ). Thus, the aeration efficiency seemed to be highest for the AMF/O emulsion, which contained the lowest content of crystalline fat as evaluated by DSC from the melting reaction (Bazmi et al., 2007). As a result, the emulsion enriched with saturated TAG required a longer whipping time to reach a given overrun value. Longer whipping times may result in excessive protein aggregation and low interfacial activity, which decrease the final overrun (Lau and Dickinson, 2004). The evolution of whipping properties was further investigated at the microstructural level by analyzing microscopic images of the whipped emulsions (Figure 4). Image analysis of at least 1,400 air bubbles per sample was performed for evaluation of $\mathrm{d}_{(0.1)}, \mathrm{d}_{(0.5)}$, and $\mathrm{d}_{(0.9)}$, the average size values corresponding to 10,50 , and $90 \%$

Table 2. Whipping ability and air bubble size characteristics ${ }^{1}$ obtained from image analysis of light microscopy images of whipped emulsions before and after aging

\begin{tabular}{|c|c|c|c|c|c|c|c|}
\hline Item $^{2}$ & $\begin{array}{l}\text { Aging } \\
\text { time (h) }\end{array}$ & $\mathrm{d}_{(0.1)}(\mu \mathrm{m})$ & $\mathrm{d}_{(0.9)}(\mu \mathrm{m})$ & Span & $\mathrm{d}_{(0.5)}(\mu \mathrm{m})$ & $\begin{array}{c}\% \mathrm{D} \\
(<50 \mu \mathrm{m})\end{array}$ & Overrun $(\%)$ \\
\hline \multirow[t]{2}{*}{$\mathrm{AMF} / \mathrm{S}$} & 2 & 9.3 & 100.8 & 3.7 & 24.8 & 72 & $127 \pm 5$ \\
\hline & 24 & 9.6 & 82.3 & 2.7 & 26.5 & 75 & $87 \pm 4$ \\
\hline \multirow[t]{2}{*}{$\mathrm{AMF}$} & 2 & 8.4 & 81.2 & 3.4 & 21.3 & 78 & $116 \pm 4$ \\
\hline & 24 & 9.7 & 67.5 & 2.5 & 23.4 & 82 & $85 \pm 2$ \\
\hline \multirow[t]{2}{*}{$\mathrm{AMF} / \mathrm{O}$} & 2 & 8.3 & 67.2 & 3.0 & 19.6 & 85 & $138 \pm 3$ \\
\hline & 24 & 9.7 & 60.1 & 2.2 & 23 & 84 & $106 \pm 5$ \\
\hline
\end{tabular}

${ }^{1} \mathrm{~d}_{0.1}, \mathrm{~d}_{0.5}$, and $\mathrm{d}_{0.9}$ are the size values corresponding to 10,50 , and $90 \%$ of the cumulative particle size distribution; $\% \mathrm{D}(<50 \mu \mathrm{m})$ values correspond to the percentage of air bubbles $<50 \mu \mathrm{m}$.

${ }^{2}$ Anhydrous milk fat (AMF) was partially replaced by a milk stearin-rich (AMF/S) or olein-rich (AMF/O) fraction; see text. 
of the cumulative particle size distribution; \%D $(<50$ $\mu \mathrm{m})$ values correspond to the percentage of air bubbles $<50 \mu \mathrm{m}$. The $\left[\mathrm{D}_{(0.9)}-\mathrm{D}_{(0.1)}\right] / \mathrm{D}_{(0.5)}$ values found in the 3 aerated emulsions were used to evaluate their degree of air bubble size homogeneity (span). The results reported in Table 2 showed that approximately $25 \%$ of air bubbles were larger than $50 \mu \mathrm{m}$ in the AMF/S foamed emulsion, compared with approximately $15 \%$ in the $\mathrm{AMF}$ and $\mathrm{AMF} / \mathrm{O}$ foamed emulsions, whereas the $\left[\mathrm{D}_{(0.9)}\right.$ $\left.-\mathrm{D}_{(0.1)}\right] / \mathrm{D}_{(0.5)}$ value (span) was lower for the AMF/O (approximately 2.19) and higher for the AMF/S (approximately 2.74) whipped emulsions than for the AMF (approximately 2.50) whipped emulsion. Thus, a higher proportion of air seemed to be incorporated into the $\mathrm{AMF} / \mathrm{O}$ emulsion, which contained a lower crystalline fat content (as evaluated by its lower melting energy; Bazmi et al., 2006, 2007), and air bubbles presented a more homogeneous and monodisperse size distribu- tion (as evaluated from $\left[\mathrm{D}_{(0.9)}-\mathrm{D}_{(0.1)}\right] / \mathrm{D}_{(0.5)}$ values), and a lower $\mathrm{D}_{(0.5)}$ value (median size). Increasing the monodispersity and the size of bubbles will minimize the buoyancy effect and the vertical stratification of bubbles in the foam. Increasing the homogeneity of the air bubble size distribution and having similarly sized bubbles avoids Ostwald ripening by reducing the Laplace pressure difference between the adjacent air bubbles (Zuniga and Aguilera, 2008; Figure 5). Air cells in the $\mathrm{AMF} / \mathrm{O}$ foamed emulsion, which contained less crystalline fat and a lower proportion of air bubbles of $\% \mathrm{D}(<50 \mu \mathrm{m})$, and conversely, air cells in the AMF/S emulsion, which contained a higher solid fat content and a higher $\% \mathrm{D}(<50 \mu \mathrm{m})$ value, could have different stabilities against coalescence and liquid drainage. In the present study, foam stability was not studied, but we did not observe any foam floating for more than 30 min after whipping. However, from differences in
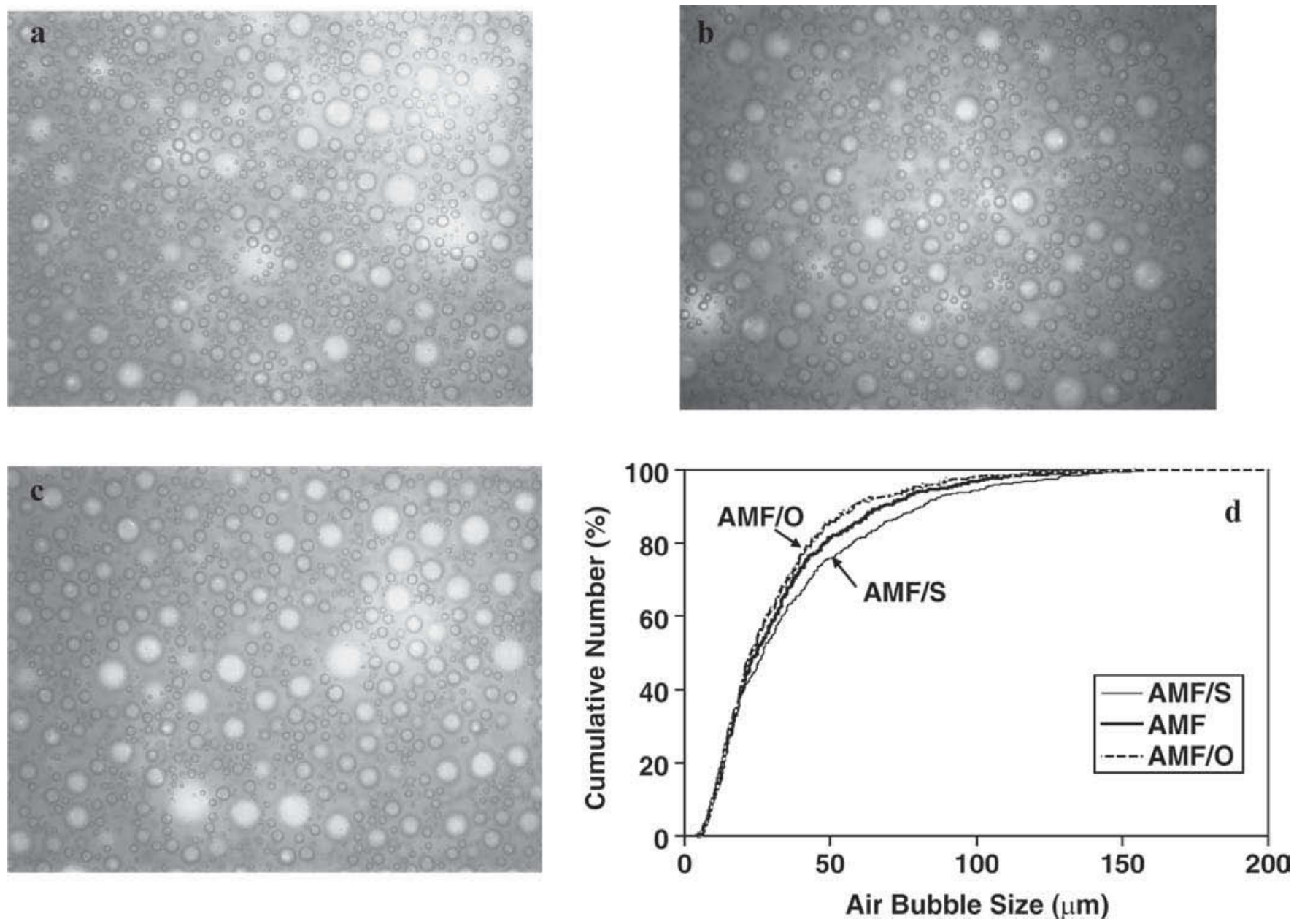

Figure 4. Microscopic images of the whipped emulsions made with (a) anhydrous milk fat (AMF) alone, (b) a mixture of AMF and olein $(\mathrm{AMF} / \mathrm{O})$, or $(\mathrm{c})$ a mixture of $\mathrm{AMF}$ and stearin $(\mathrm{AMF} / \mathrm{S})$, and (d) the size distribution of air bubbles obtained from whipped emulsion image analysis. 

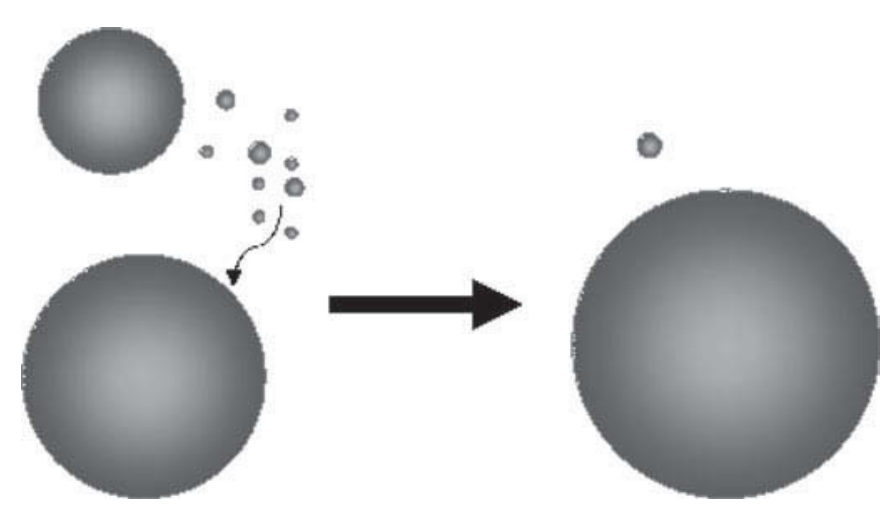

Figure 5. Instability mechanism in the foams caused by Ostwald ripening - the growth of large bubbles at the expense of small ones caused by gas diffusion between them, which was accelerated by the Laplace pressure difference between the adjacent air bubbles.

air bubble size distributions (Chang and Hartel, 2002; Goff, 2002) and their relation to Laplace pressure differences (pressure gradient), longer stability times could be expected for the AMF/O whipped emulsions.

\section{CONCLUSIONS}

The foaming ability of the oil-in-water emulsions was affected by processing conditions: increasing the pasteurization holding time as well as the aging time reduced the foaming ability of the emulsions. In other words, a longer whipping time would be needed to reach a predefined overrun value. However, according to our findings, this behavior was not necessarily a negative quality parameter. By increasing the aging time, more homogeneous air bubble size distributions were obtained, which led to more stable foam structures. In addition, enrichment of AMF with the olein-rich fraction enhanced the whipping ability of the emulsion and made it healthier by reducing the amount of saturated TAG in the formulation.

\section{REFERENCES}

Abd El-Rahman, A. M., S. A. Madkor, F. Ibrahim, and A. Kilara. 1997. Physical characteristics of frozen desserts made with cream, anhydrous milk fat, or milk fat fractions. J. Dairy Sci. 80:19261935.

Adapa, S., H. Dingeldein, K. A. Schmidt, and T. J. Herald. 2000. Rheological properties of ice cream mixes and frozen ice creams containing fat and fat replacers. J. Dairy Sci. 83:2224-2229.

Baer, A., M. Oroz, and B. Blanc. 1976. Serological studies on heatinduced interactions of $\alpha$-lactalbumin and milk proteins. J. Dairy Res. 143:419-432.

Bazmi, A., A. Duquenoy, and P. Relkin. 2007. Aeration of low-fat dairy emulsions: Effects of saturated-unsaturated triglycerides. Int. Dairy J. 17:1021-1027.

Bazmi, A., B. Launay, G. Cuvelier, A. Duquenoy, A. Sommier, and P. Relkin. 2006. Effect of ageing time at $4^{\circ} \mathrm{C}$ on rheological and structural properties of ice cream mix models: Impact of milk fat composition. Pages 189-193 in Int. Symp. Food Rheology and
Structure Congr., Zurich, Switzerland. Institute of Food Science and Nutrition, Zurich, Switzerland.

Bazmi, A., B. Launay, G. Cuvelier, and P. Relkin. 2008. Rheological properties of ice cream mix model systems, as affected by ageing time at $4^{\circ} \mathrm{C}$ and milk fat composition. J. Texture Stud. 39:309325.

Bazmi, A., and R. Relkin. 2006. Thermal transitions and fat droplet stability in ice-cream model systems: Effect of milk fat fractions. J. Therm. Anal. Calorimetry 84:99-104.

Berger, K. G. 1990. Ice cream. Pages 367-444 in Food Emulsions. K. Larsson and S. E. Friberg, ed. Marcel Dekker Inc., New York, NY.

Bolliger, S., H. D. Goff, and B. W. Tharp. 2000. Correlation between colloidal properties of ice cream mix and ice cream. Int. Dairy J. 10:303-309.

Boode, K., and P. Walstra. 1993. Partial coalescence in oil-inwater emulsions 1. Nature of the aggregation. Colloids Surf. A, Physicochem. Eng. Asp. 81:121-137.

Bruhn, C. M., and J. C. Bruhn. 1988. Observations on the whipping characteristics of cream. J. Dairy Sci. 71:857-862.

Chang, Y., and R. W. Hartel. 2002. Development of air cells in a batch ice cream freezer. J. Food Eng. 55:71-78.

Dannenberg, F., and H. G. Kessler. 1988. Reaction kinetics of the denaturation of whey proteins. J. Food Sci. 53:258-263.

Davies, E., E. Dickinson, and R. Bee. 2000. Shear stability of sodium caseinate emulsions containing monoglyceride and triglyceride crystals. Food Hydrocoll. 14:145-153.

De Wit, J. N., and G. Klarenbeek. 1981. A different scanning calorimetric study of thermal behavior of bovine $\beta$-lactoglobolin at temperatures up to $160^{\circ} \mathrm{C}$. J. Dairy Res. 48:293-302.

Eisner, M. D., H. Wildmoser, and E. J. Windhalb. 2005. Air cell microstructureing in a high visous ice cream matrix. Colloids Surf. A, Physicochem. Eng. Asp. 263:390-399.

Goff, H. D. 1997a. Colloidal aspects of ice cream-A review. Int. Dairy J. 7:363-373.

Goff, H. D. 1997b. Instability and partial coalescence in whippable dairy emulsion. J. Dairy Sci. 80:2620-2630.

Goff, H. D. 2002. Formation and stabilization of structure in ice cream and related products. Curr. Opin. Colloid Interface Sci. 7:432437.

Goff, H. D., E. Verespej, and A. K. Smith. 1999. A study of fat and air structures in ice cream. Int. Dairy J. 9:817-829.

Graf, E., and H. R. Muller. 1965. Fine structure and whippability of sterilized cream. Milchwissenschaft 20:302-308.

Granger, C., P. Barey, N. Combe, P. Veschambre, and M. Cansell. 2003. Influence of the fat characteristics on the physicochemical behavior of oil-in-water emulsions based on milk proteins-glycerol esters mixtures. Colloids Surf. B, Biointerfaces 32:353-363.

Granger, C., A. Leger, P. Barey, V. Langendorff, and M. Cansell. 2005. Influence of formulation on the structural network in ice cream. Int. Dairy J. 15:255-262.

Gresti, J., M. Bugaut, C. Maniongui, and J. Bezard. 1993. Composition of molecular species of triacylglycerols in bovine milk fat. J. Dairy Sci. $76: 1850-1869$.

Herrera, M. L., M. de León Gatti, and R. W. Hartel. 1999. A kinetic analysis of crystallization of a milk fat model system. Food Res. Int. 32:289-298.

Indrawati, L., Z. Wang, G. Narsimhan, and J. Gonzalez. 2008. Effect of processing parameters on foam formation using a continuous system with a mechanical whipper. J. Food Eng. 88:65-74.

Kulozik, U., A. Tolkach, S. Bulca, and J. Hinrichs. 2003. The role of processing and matrix design in development and control of microstructures in dairy food production-A survey. Int. Dairy J. 13:621-630.

Lau, C., and E. Dickinson. 2004. Structural and rheological properties of aerated high sugar systems containing egg albumin. J. Food Sci. 69:232-239.

Livney, Y. D., M. Corredig, and D. G. Dalgleish. 2003. Influence of thermal processing on the properties of dairy colloids. Curr. Opin. Colloid Interface Sci. 8:359-364. 
Marshall, R. T., and W. S. Arbuckle. 1996. Ice Cream. Chapman and Hall, New York, NY 349.

Michon, C., C. Chapuis, V. Langendorff, P. Boulenguer, and G. Cuvelier. 2005. Structure evolution of carrageenan/milk gels: Effect of shearing, carrageenan concentration and nu fraction on rheological behavior. Food Hydrocoll. 19:541-547.

Olsen, S. 1992. Ageing of ice cream mix. Scand. Dairy Inf. 6:63-65.

Palanuwech, J., and J. N. Coupland. 2003. Effect of surfactant type on the stability of oil-in-water emulsions to dispersed phase crystallization. Colloids Surf. A, Physicochem. Eng. Asp. $223: 251-262$.

Peamprasart, Y., and N. Chiewchan. 2006. Effect of fat content and preheat treatment on the apparent viscosity of coconut milk after homogenization. J. Food Eng. 77:653-658.

Rahalkar, R. R. 1992. Viscoelastic properties of oil-water emulsions. Pages 317-354 in Viscoelastic Properties of Foods. M. R. Rao and J. F. Steffe, ed. Elsevier Applied Science, London, UK.

Relkin, P. 1996. Thermal unfolding of $\beta$-lactoglobulin and $\alpha$-lactoalbumin and bovine serum albumin - A thermal dynamic approach. Crit. Rev. Food Sci. Nutr. 36:565-601.

Relkin, P., and S. Sourdet. 2005. Factors affecting fat droplet aggregation in whipped frozen protein-stabilized emulsions. Food Hydrocoll. 19:503-511.
Rousseau, D. 2000. Fat crystals and emulsion stability-A review. Food Res. Int. 33:3-14

Sherman, P. 1966. The texture of ice cream: 3. Rheological properties of mix and melted ice cream. J. Food Sci. 31:707-716.

Sherman, P. 1968. Rheology of emulsions. Pages 217-354 in Emulsion Science. P. Sherman, ed. Academic Press, London, UK.

Smith, A. K., H. D. Goff, and Y. Kakuda. 2000a. Microstructure and rheological properties of whipped cream as affected by heat treatment and addition of stabilizer. Int. Dairy J. 10:295-301.

Smith, A. K., Y. Kakuda, and H. D. Goff. 2000b. Changes in protein and fat structure in whipped cream caused by heat treatment and addition of stabilizer to the cream. Food Res. Int. 33:697-706.

Sourdet, S., P. Relkin, and B. César. 2003. Effects of milk protein type and pre-heating on physical stability of whipped and frozen emulsions. Colloids Surf. B, Biointerfaces 31:55-64.

Sourdet, S., P. Relkin, P.-Y. Fosseux, and V. Aubry. 2002. Composition of fat protein layer in complex food emulsions at various weight ratios of casein-to-whey proteins. Lait 82:567-578.

Vega, G., and H. D. Goff. 2005. Phase separation in soft-serve ice cream mixes: Rheology and microstructure. Int. Dairy J. 15:249-254.

Zuniga, R. N., and J. M. Aguilera. 2008. Aerated food gels: Fabrication and potential applications. Trends Food Sci. Technol. 19:176187. 